\title{
Effect of the diel cycle on production of dimethylsulfoniopropionate in batch cultures of Emiliania huxleyi
}

\author{
Eva Bucciarelli ${ }^{1, *}$, William G. Sunda ${ }^{2}$, Sauveur Belviso ${ }^{3}$, Géraldine Sarthou ${ }^{1}$ \\ ${ }^{1}$ LEMAR, UMR CNRS 6539, IUEM, Place Nicolas Copernic, 29280 Plouzané, France \\ ${ }^{2}$ CCFHR, NOS, NOAA, 101 Pivers Island Rd., Beaufort, North Carolina 28516, USA \\ ${ }^{3}$ LSCE, UMR CEA-CNRS 1572, CEN de Saclay, Bât 701 l'Orme des Merisiers, 91191 Gif-sur-Yvette, France
}

\begin{abstract}
Changes in intracellular dimethylsulfoniopropionate (DMSP), nitrogen, carbon, chlorophyll a (chl a), total cell volume and cell numbers were measured during day and night in axenic, exponentially growing batch cultures of the coccolithophorid, Emiliania huxleyi, cultured at $20^{\circ} \mathrm{C}$ under a $12 \mathrm{~h}$ light: $12 \mathrm{~h}$ dark cycle. Cellular DMSP content in the cultures increased at a specific rate of $0.80 \pm 0.10 \mathrm{~d}^{-1}$ (mean $\pm \mathrm{SE}$ ) during the day and $0.53 \pm 0.12 \mathrm{~d}^{-1}$ at night. By contrast, cellular carbon and chl a content of the culture and total cell volume increased only during the day (at specific rates of $1.30 \pm 0.08 \mathrm{~d}^{-1}, 1.54 \pm 0.12 \mathrm{~d}^{-1}$ and $1.39 \pm 0.12 \mathrm{~d}^{-1}$, respectively). Cellular nitrogen content of the culture showed a much higher specific rate of increase during the day $\left(1.07 \pm 0.07 \mathrm{~d}^{-1}\right)$ than at night $\left(0.22 \pm 0.03 \mathrm{~d}^{-1}\right)$. Because intracellular DMSP had a lower specific rate of synthesis during the day and a higher specific rate at night than specific production rates for the various cell biomass parameters (total cell volume, and cell carbon, nitrogen and chl a), ratios of DMSP to these parameters were highest at the end of the dark period and decreased during the day. The maximum intracellular DMSP concentrations at the beginning of the light period may provide some level of protection from oxidative stress with the daytime initiation of photosynthesis. Significant intracellular production of DMSP during the night contradicts current conventional wisdom, which assumes that no nighttime biosynthesis of DMSP occurs. Previous calculations based on this invalid assumption will need to be reassessed.
\end{abstract}

KEY WORDS: Diel cycle $\cdot$ Dimethylsulfoniopropionate $\cdot$ DMSP $\cdot$ Emiliania huxleyi

\section{INTRODUCTION}

One of the major scientific issues of this century is to understand the regulation of the earth's climate system. Of particular importance is the influence of sulfate aerosols on cloud formation and the solar reflectance of the atmosphere (IPCC 2001). Global anthropogenic sulfur emissions are estimated to be ca. $80 \mathrm{Tg} \mathrm{yr}^{-1}$ and total natural inputs of sulfur are ca. $34 \mathrm{Tg} \mathrm{yr}^{-1}$ (IPCC 2001). More than $90 \%$ of the oceanic sulfur flux of $24 \mathrm{Tg} \mathrm{yr}^{-1}$ is derived from dimethylsulfide (DMS), a volatile compound that oxidizes in the atmosphere to form sulfate aerosols. These serve as cloud condensation nuclei and thereby influence the planetary albedo and radiative forcing (Charlson et al. 1987). DMS is derived from the enzymatic cleavage of dimethylsulfoniopropionate (DMSP) by phytoplankton and bacteria (Kiene 1990, Stefels \& van Boekel 1993). Environmental factors that regulate primary production influence DMS production. For example, Sunda et al. (2007) suggested that $\mathrm{N}$ limitation may play a role in climate feedback mechanisms involving biologically derived DMS. Changes in DMS production by phytoplankton may also be primarily responsible for trends seen in cloud albedo over the North Atlantic (Falkowski et al. 1992).

DMSP is present at high intracellular concentrations ( 0.1 to $0.4 \mathrm{~mol}_{\text {cell }^{-1}}{ }^{-1}$ ) in many species of phytoplankton, 
including the coccolithophorid, Emiliania huxleyi (Keller et al. 1989). This ubiquitous species blooms in vast oceanic areas and is thought to play an important role in the global carbon and sulfur cycles (Westbroek et al. 1993). DMSP, DMS and their oxidation product dimethylsulfoxide (DMSO) are part of a highly dynamic chemical system whose variations in time and space are still being discovered. DMSP appears to have a variety of biological functions: it functions as an osmolyte (Vairavamurthy et al. 1985) and has been proposed to serve as an active chemical defense mechanism against grazing (Wolfe et al. 1997) and as a photosynthetic energy 'overflow' molecule (Stefels 2000). It may also function as the first link of an intracellular antioxidant system involving DMSP, its enzymatic breakdown products (DMS and acrylate) and DMSO (Sunda et al. 2002, Bucciarelli \& Sunda 2003). Hydroxyl radicals and other reactive oxygen species (ROS) are byproducts of photosynthesis (Foyer 1996) and, thus, if DMSP serves as a cellular antioxidant, it may be expected to vary with diel variations in light and photosynthesis.

In this study, we examined the diel variations in DMSP and DMS in axenic batch cultures of Emiliania huxleyi grown under a $12 \mathrm{~h}$ light:12 h dark cycle. We also measured cellular nitrogen, cellular carbon, chl $a$, total cellular volume, volume per cell and specific growth rate. This study allowed us to quantify the diel production of DMSP during exponential growth of $E$. huxleyi and to identify diel patterns in intracellular DMSP concentrations. Our results have implications for the potential role of DMSP in antioxidant protection and help provide a better understanding of the processes that influence DMSP in oceanic waters.

\section{MATERIALS AND METHODS}

Culture conditions. Axenic batch cultures of Emiliania huxleyi (CCMP 374, a noncalcifying clone according to microscopic observations by CCMP) were grown at $20^{\circ} \mathrm{C}$ in polycarbonate bottles with no headspace, containing $1200 \mathrm{ml}$ of medium. Cultures were grown under cool white fluorescent light at an irradiance of $100 \mu \mathrm{mol}$ photons $\mathrm{m}^{-2} \mathrm{~s}^{-1}$ and a $12 \mathrm{~h}$ light: $12 \mathrm{~h}$ dark cycle. The complete medium consisted of filtered $(0.4 \mu \mathrm{m}) 34 \mathrm{psu}$ salinity Southern Ocean seawater enriched with $32 \mu \mathrm{mol} \mathrm{l}^{-1}$ nitrate, $2 \mu \mathrm{mol} \mathrm{l}^{-1}$ phosphate, $0.1 \mu \mathrm{g} \mathrm{l}^{-1}$ vitamin $\mathrm{B}_{12}, 0.1 \mathrm{\mu g} \mathrm{l}^{-1}$ biotin, $20 \mathrm{\mu g} \mathrm{l}^{-1}$ thiamin and $10 \mathrm{nmol} \mathrm{l}^{-1}$ selenite (Bucciarelli \& Sunda 2003). The medium also contained a trace metal ion buffer system consisting of $0.1 \mathrm{mmol} \mathrm{l}^{-1}$ nitrilotriacetic acid (NTA), $1.5 \mathrm{nmol} \mathrm{l}^{-1} \mathrm{Cu}, 3.2 \mathrm{nmol} \mathrm{l}^{-1} \mathrm{Co}, 12 \mathrm{nmol} \mathrm{l}^{-1} \mathrm{Zn}$, $5 \mathrm{nmol} \mathrm{l}^{-1} \mathrm{Mn}$, and $100 \mathrm{nmol} \mathrm{l}^{-1} \mathrm{Fe}$. The buffer system generated free ion concentrations of $\mathrm{Cu}, \mathrm{Co}, \mathrm{Zn}$ and
Mn of $10^{-13.2}, 10^{-10.3}, 10^{-10.0}$ and $10^{-8.3} \mathrm{~mol} \mathrm{l}^{-1}$, respectively, based on equilibrium calculations (Bucciarelli \& Sunda 2003). The culture media were sterilized by microwave treatment. The cultures were grown under axenic conditions, and axenicity was checked for each sampling by pipeting $1 \mathrm{ml}$ culture aliquots into sterile peptone media and then verifying the absence of bacterial growth.

Four replicate cultures (R1, R2, R3 and R4) were inoculated from the same initial culture. Seven days later, when the cultures reached a sufficient biomass, the experiment was initiated. Cultures R1 and R2 were sampled at the beginning of the light period and approximately every $4 \mathrm{~h}$ thereafter over $24 \mathrm{~h}$. Cultures R3 and R4 were sampled $\sim 2 \mathrm{~h}$ after R1 and R2. Each sample was analyzed for total cell concentration $(\mathrm{CC})$, average volume per cell $\left(\mathrm{V}_{\text {cell }}\right)$, and particulate (i.e. intracellular) chl $a$, carbon $(\mathrm{C})$, and nitrogen $(\mathrm{N})$. The cultures were also analyzed for intracellular DMSP and dissolved DMSP and DMS. After each sampling, new medium was added to refill the bottles and thereby mimimize DMS exchange with the atmosphere. Potential loss from the bottles was determined by measuring dissolved DMS over an $11 \mathrm{~d}$ period in 3 polycarbonate bottles filled with sterile seawater with no headspace. The initial DMS concentration was $42.9 \pm 2.1 \mathrm{nmol} \mathrm{l}^{-1}$ (mean $\pm \mathrm{SD}, \mathrm{n}=6$ ) and decreased to $21.8 \pm 1.8 \mathrm{nmol} \mathrm{l^{-1 }}(\mathrm{n}=6)$. A linear regression of the natural log of the DMS concentration versus time yielded a specific loss rate of $-0.063 \pm$ $0.004 \mathrm{~d}^{-1}\left(\mathrm{r}^{2}=0.94, \mathrm{n}=18\right)$ or $6.3 \% \mathrm{~d}^{-1}$.

Cell concentrations, volume per cell and specific growth rate. No Coulter counter was available on site, so cellular concentrations $\left(\mathrm{CC}\right.$, cells $\mathrm{ml}_{\text {medium }}{ }^{-1}$ ) were determined by microscopic counts. During the diel cycle $10 \mathrm{ml}$ of each culture was fixed with $600 \mu \mathrm{l}$ of $25 \%$ glutaraldehyde and the volume per cell $\left(\mathrm{V}_{\text {cell }}\right.$ $\mu^{3}$ ) was measured a week later with a Z2 Coulter electronic particle counter. The glutaraldehyde treatment was found to have no effect on cell volume (data not shown). Cell volume per liter of culture $\left(\mathrm{CV}, \mu \mathrm{l}_{\text {cell }}\right.$ $1_{\text {medium }}{ }^{-1}$ ) was calculated from $C C \times V_{\text {cell }}$. Specific growth rate $\left(\mu, \mathrm{d}^{-1}\right)$ was determined by linear regression of the natural log of $\mathrm{CV}$ versus time after accounting for culture dilution. The cells exhibited a constant daily specific growth rate over several days before the experiment and experienced no nutrient limitation before or during the experiment.

Intracellular DMSP, dissolved DMSP and DMS. To measure intracellular DMSP, dissolved DMSP $\left(\mathrm{DMSP}_{\mathrm{d}}\right)$ and dissolved DMS, three pairs of samples were withdrawn from the cultures. The first pair (50 to $100 \mu \mathrm{l}$ of culture) was placed in $8 \mathrm{ml}$ glass septum vials containing $5 \mathrm{~mol} \mathrm{l}^{-1} \mathrm{NaOH}$, which converted intracellular and dissolved DMSP into DMS. The vials were immedi- 
ately sealed and then the released DMS plus that originally present was measured by gas chromatography with a VARIAN pulsed flame photometric detector (Belviso et al. 2000). This yielded concentrations of total DMSP plus DMS. Two other $5 \mathrm{ml}$ pairs of culture samples were filtered by gravity pressure onto glass fiber filters $(\mathrm{GF} / \mathrm{F})$, and the resulting filtrates were analyzed as above. The first set of filtrates was analyzed without further treatment and yielded concentrations of dissolved DMSP plus DMS. The second pair was degassed and their analysis yielded only dissolved DMSP. Intracellular DMSP was computed by subtracting the concentration of dissolved DMSP plus DMS from the total DMSP plus DMS concentration. DMS was computed from the difference in the DMS concentration measured in the whole and degassed culture filtrates. This was done because direct DMS measurements would have had to be performed immediately after sampling, and all the sulfur analyses were performed together after completion of the experiment.

Cellular nitrogen, carbon and chl $\mathbf{a}$. To measure cel-

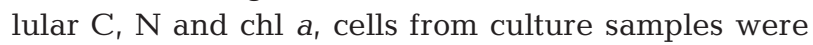
filtered onto glass fiber filters (GF/F). Chl a was measured by fluorometry after extraction into $90 \%$ acetone (Lorensen 1966). All glassware used for cell C and $\mathrm{N}$ determination (filter holders, filtration funnels and vials) was washed with $10 \% \mathrm{HCl}$, rinsed with Milli-Q water and dried. Glassware was then precombusted at $450^{\circ} \mathrm{C}$ for $4.5 \mathrm{~h}$, as were the GF/F filters used for the filtrations. Samples were stored frozen at $-20^{\circ} \mathrm{C}$ and were dried before analysis. Inorganic $\mathrm{C}$ was removed from the cellular $\mathrm{C}$ samples before analysis by fuming the filters with concentrated $\mathrm{HCl}$ (Paasche 1998). Samples were analyzed using a Carlo-Erba NA-1500 elemental analyzer.

Intracellular concentrations of DMSP were expressed on a cell volume basis $\left(\mathrm{mol}_{\text {cell }^{-1}}\right)$ as well as on a per cell, cell $\mathrm{C}$, cell $\mathrm{N}$, and chl a basis. Culture concentrations of dissolved DMSP and DMS were expressed in units of nmol $l_{\text {medium }}{ }^{-1}$. To allow comparisons with intracellular DMSP, dissolved DMSP and DMS were also normalized to total cell volume.

Slight differences in the biomass of the replicate experimental cultures existed at the beginning of the experiment $\left(5.0,6.7,7.8\right.$ and $6.6 \mu \mathrm{l}_{\text {cell }} \mathrm{l}_{\text {medium }}{ }^{-1}$, respectively, for R1, R2, R3 and R4 at t = 0) due to initial differences in the inoculum biomass or slight differences in algal growth rate during the $7 \mathrm{~d}$ of culture growth before commencement of diel measurements. To account for these biomass differences we recomputed the first point of replicates R2, R3 and R4 to align with $\mathrm{R} 1$ values between $\mathrm{t}=0 \mathrm{~h}$ and $\mathrm{t}=4 \mathrm{~h}$. A translation of the data was applied to R2, R3 and R4 so that the 4 replicates theoretically began at the same point.

\section{RESULTS}

Consistent diel patterns were observed for the 4 replicate cultures. Consequently, data for the 4 replicates are plotted together. The dark period is represented by the grey shaded area in the figures. The intracellular DMSP normalized to different cellular parameters (number of cells, total cell volume, and cellular $\mathrm{C}, \mathrm{N}$ and chl a) showed distinct diel patterns.

\section{Specific growth rate}

The combined specific growth rate of the 4 replicates (based on total cell volume, Fig. 1c) was $1.39 \pm 0.12$ (mean $\pm \mathrm{SE}$ ) during the day, and $-0.19 \pm 0.19 \mathrm{~d}^{-1}$ at night (Table 1). The overall average daily specific growth rate was $0.63 \pm 0.11 \mathrm{~d}^{-1}\left(\mathrm{r}^{2}=0.60, \mathrm{n}=24, \mathrm{p}<\right.$ 0.01 ), similar to that measured during the $7 \mathrm{~d}$ before
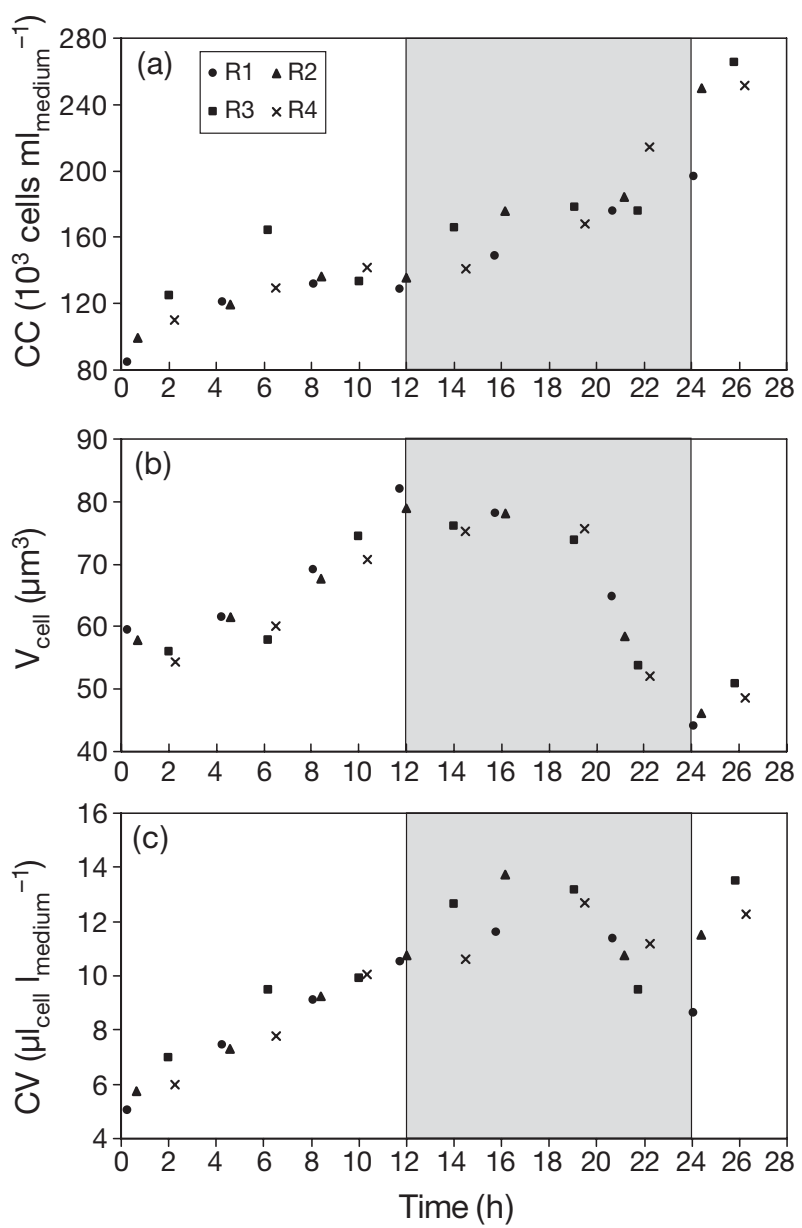

Fig. 1. Emiliania huxleyi. (a) Cell concentration $\left(\mathrm{CC} ; 10^{3}\right.$ cells $\left.\mathrm{ml}_{\text {medium }}{ }^{-1}\right)$, (b) volume per cell $\left(\mathrm{V}_{\text {celli }} \mu_{\mathrm{m}}^{3}\right)$ and (c) total cell volume $\left(\mathrm{CV}_{i} \mu \mathrm{l}_{\text {cell }} \mathrm{l}_{\text {medium }}{ }^{-1}\right)$ versus time $(\mathrm{h})$. Night is represented by the grey shaded area. R1, R2, R3 and R4 are replicate cultures 
Table 1. Emiliania huxleyi. Regression slopes (mean $\left.\pm \mathrm{SE}, \mathrm{d}^{-1}\right)$ during the light ( 0 to $12 \mathrm{~h}$ ) and dark period (12 to $\left.24 \mathrm{~h}\right)$ of time dependent plots of the natural $\log (\mathrm{ln})$ of total cell volume $\left(\mathrm{CV}, \mu \mathrm{l}_{\text {cell }} \mathrm{l}_{\text {medium }}{ }^{-1}\right)$ and cellular carbon, nitrogen, chlorophyll $a$ and DMSP (dimethylsulfoniopropionate) per liter of culture (all expressed in mol $\mathrm{l}_{\text {medium }}{ }^{-1}$ ). The number of data points (n), correlation coefficient $\left(\mathrm{r}^{2}\right)$, and $\mathrm{p}$-value are also given

\begin{tabular}{|c|c|c|c|c|c|}
\hline & $\mathrm{CV}$ & $\mathrm{C}$ & $\mathrm{N}$ & Chl a & DMSP \\
\hline \multicolumn{6}{|l|}{ Light } \\
\hline Specific rate & $1.39 \pm 0.12$ & $1.30 \pm 0.08$ & $1.07 \pm 0.07$ & $1.54 \pm 0.12$ & $0.80 \pm 0.10$ \\
\hline $\mathrm{n}$ & 14 & 14 & 14 & 14 & 14 \\
\hline $\mathrm{p}$ & $<0.01$ & $<0.01$ & $<0.01$ & $<0.01$ & $<0.01$ \\
\hline$r^{2}$ & 0.91 & 0.96 & 0.95 & 0.93 & 0.84 \\
\hline \multicolumn{6}{|l|}{ Dark } \\
\hline Specific rate & $-0.19 \pm 0.19$ & $-0.01 \pm 0.06$ & $0.22 \pm 0.03$ & $-0.38 \pm 0.16$ & $0.53 \pm 0.12$ \\
\hline $\mathrm{n}$ & 14 & 14 & 14 & 14 & 14 \\
\hline $\mathrm{p}$ & 0.35 & 0.89 & $<0.01$ & 0.04 & $<0.01$ \\
\hline $\mathrm{r}^{2}$ & 0.07 & 0.002 & 0.80 & 0.31 & 0.62 \\
\hline
\end{tabular}
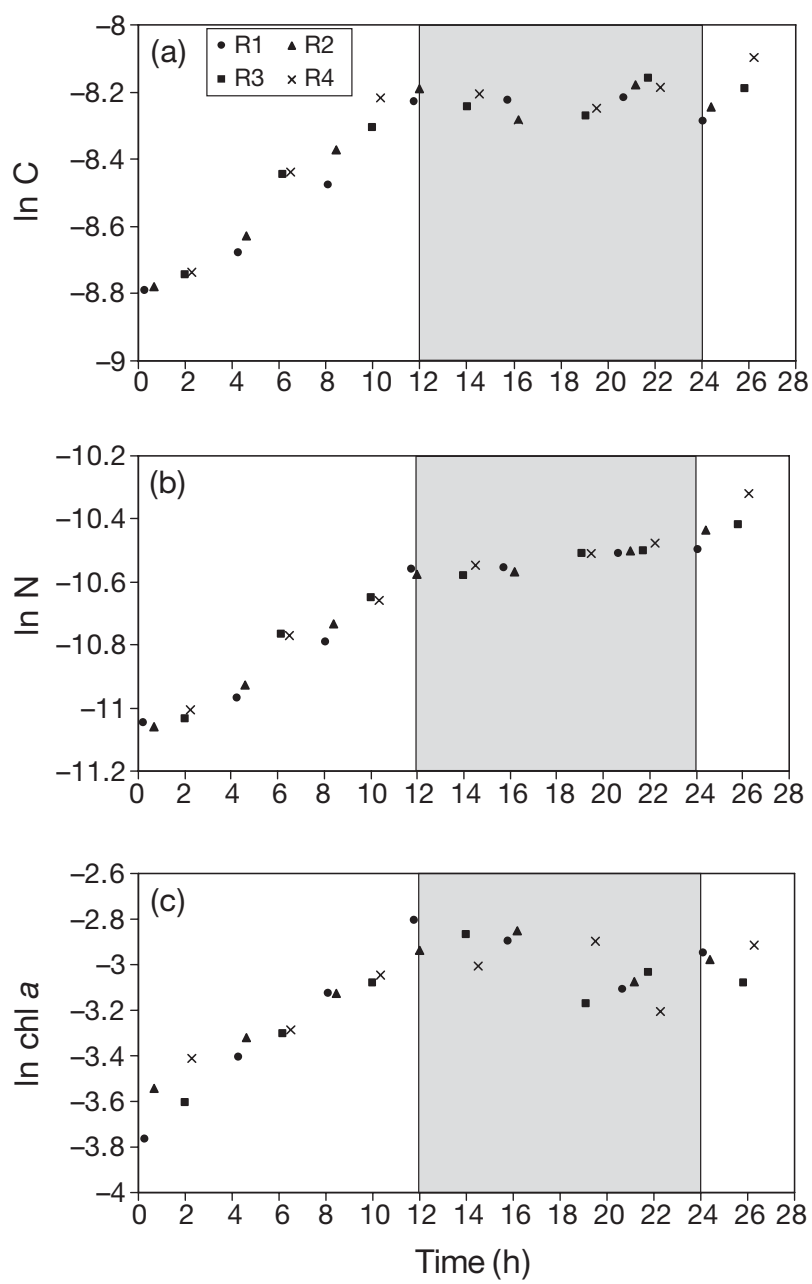

Fig. 2. Emiliania huxleyi. (a) Natural log of cellular carbon per liter of culture $\left(C_{i}\right.$ mol $\left.l_{\text {medium }}{ }^{-1}\right)$, (b) natural log of cellular nitrogen per liter of culture $\left(\mathrm{N}_{i}\right.$ mol $\left.\mathrm{l}_{\text {medium }}{ }^{-1}\right)$, and (c) natural log of cellular chlorophyll a per liter of culture (chl $a_{i} \mu \mathrm{mol}$ $1_{\text {medium }}{ }^{-1}$ ) versus time (h). Night is represented by the grey shaded area. R1, R2, R3 and R4 are replicate cultures the experiment $\left(0.70 \pm 0.02 \mathrm{~d}^{-1}, \mathrm{r}^{2}=0.99, \mathrm{n}=16, \mathrm{p}<\right.$ 0.01). Cell division took place during the night and early morning (Fig. 1a), in agreement with previous observations for Emiliania huxleyi (Paasche 1967). As a result of the combined diel patterns in growth and cell division, the volume per cell exhibited a minimum near the beginning of the light period and a maximum at the end (Fig. 1b). The maximum rate of cell division occurred during the latter part of the dark period (Fig. 1a) and consequently cell size decreased the most during this time (Fig. 1b).

Diel patterns of increases in cellular $\mathrm{C}, \mathrm{N}$ and chl a (per liter of culture) were also examined (Fig. 2). The specific rates of increase during the day and night were computed from regressions of the natural log of each parameter after correction for culture dilution (Table 1). During the day (0 to $12 \mathrm{~h}$ ), the specific rates of increase of cellular $\mathrm{C}$ and chl a (per liter of culture) were close to the specific growth rate $\left(1.39 \mathrm{~d}^{-1}\right)$, while the specific rate of increase of cellular $\mathrm{N}$ was lower. During the night there was no significant change in the cellular $\mathrm{C}$ content of the culture $(\mathrm{p}>0.1)$, but $\mathrm{N}$ increased significantly $(p<0.01)$ at a specific rate that was $20 \%$ of the daytime value. These patterns reflect the fact that carbon is fixed photosynthetically only during the light period, while nitrogen uptake and assimilation occurs during the day and night (Cuhel et al. 1984). Likewise, chlorophyll is clearly synthesized during the day, but based on our data it may be degraded at night (Table 1).

\section{Intracellular DMSP}

The natural log of cellular DMSP (per liter of culture, corrected for culture dilution) was also regressed versus time during the day and night (Fig. 3a). A signifi- 

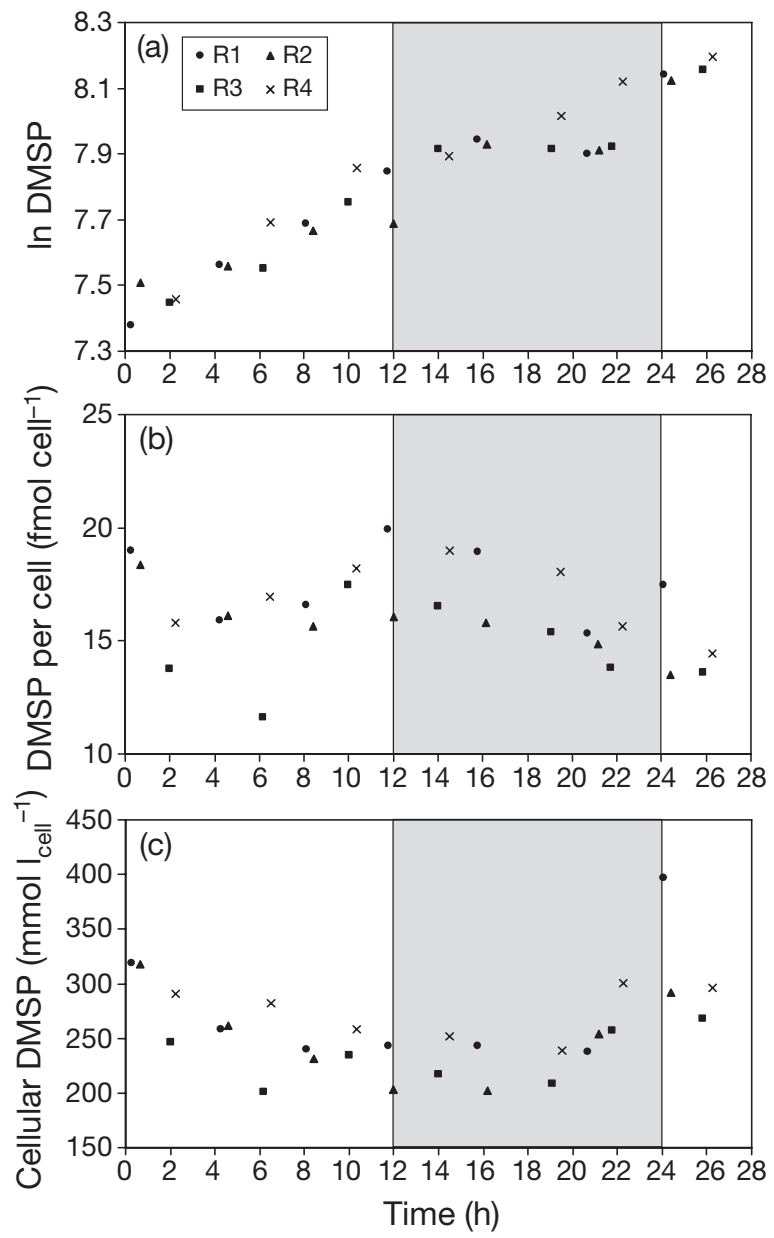

Fig. 3. Emiliania huxleyi. (a) Natural log of cellular DMSP per liter of culture (DMSP; nmol $\mathrm{l}_{\text {medium }} \mathrm{l}^{-1}$ ), (b) DMSP per cell (fmol cell ${ }^{-1}$ ), and (c) intracellular DMSP per liter of cell volume $\left(\mathrm{mmol} \mathrm{l}_{\text {cell }^{-1}}\right.$ ) versus time (h). Night is represented by the grey shaded area. R1, R2, R3 and R4 are replicate cultures

cant increase was observed during both the day and night (Table 1). The daytime specific production rate was about $50 \%$ higher than that at night.

Values of DMSP per cell varied between 11.6 and $19.9 \mathrm{fmol} \mathrm{cell}^{-1}$ (average: $16.2 \pm 2.0 \mathrm{fmol} \mathrm{cell}^{-1}$ ) and showed no clear diel pattern (Fig. 3b). However, because the volume per cell varied during the diel cycle, it is perhaps more relevant to consider intracellular concentrations of DMSP. The intracellular DMSP concentration (per liter of cell volume) varied over the diel cycle (Fig. 3c). The intracellular DMSP concentration was highest at the beginning of the light period (318 $\pm 1 \mathrm{mmol}_{\text {cell }^{-1}}{ }^{-1}$ at $\left.\mathrm{t}<2 \mathrm{~h}\right)$ and lowest at the end $\left(223 \pm 27 \mathrm{mmol} \mathrm{l}_{\text {cell }^{-1}}\right.$ at $\left.\mathrm{t} \sim 12 \mathrm{~h}\right)$. It remained roughly constant at $228 \pm 20 \mathrm{mmol}_{\text {cell }^{-1}}$ during the first $7 \mathrm{~h}$ of the dark period and increased during the last $5 \mathrm{~h}$. That increase was caused both by continued DMSP production (Fig. 3a) and by a measured decrease in total cell
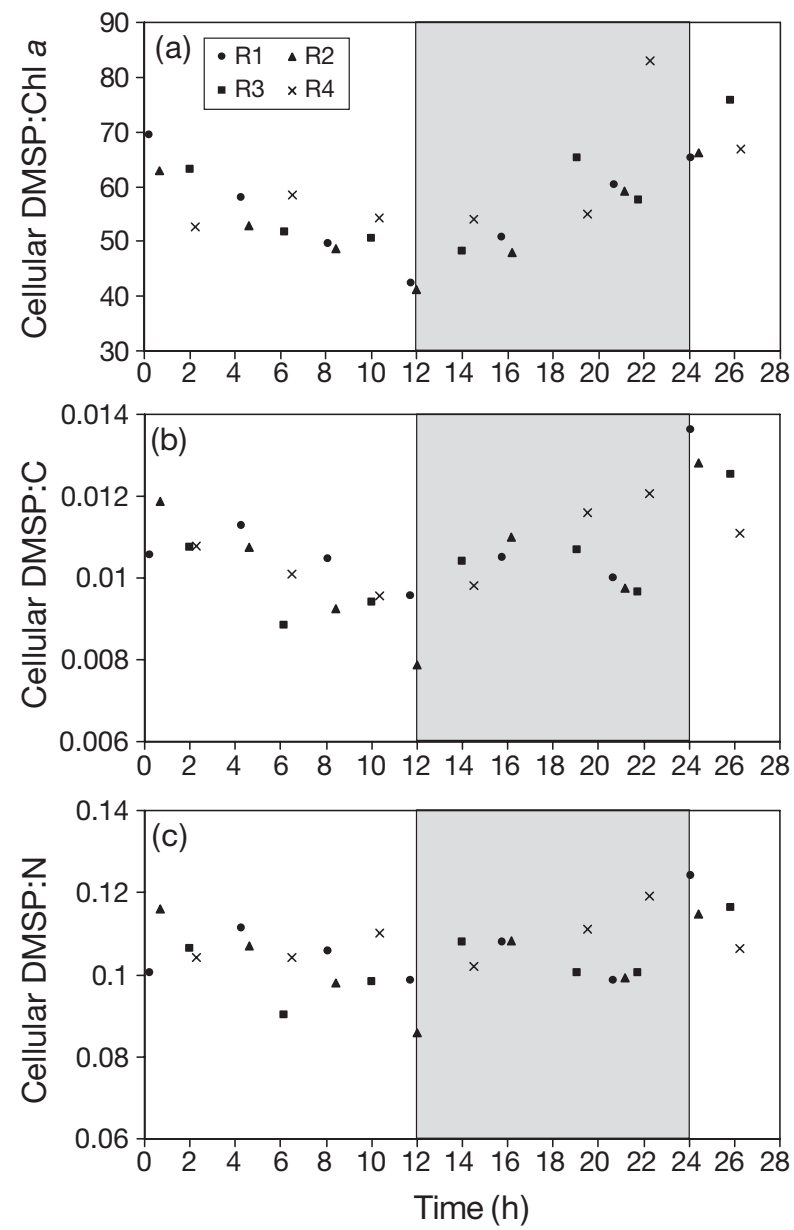

Fig. 4. Emiliania huxleyi. Ratios of (a) cellular DMSP:chl a (mol mol$\left.{ }^{-1}\right)$, (b) cellular DMSP:carbon $\left(\mathrm{mol} \mathrm{mol}^{-1}\right)$ and (c) cellular DMSP:nitrogen ( $\mathrm{mol} \mathrm{mol}^{-1}$ ) versus time $(\mathrm{h})$. Night is represented by the grey shaded area. R1, R2, R3 and R4 are replicate cultures

volume (Fig. 1c), which occurred during the period of maximum cell division (Fig. 1a) and resulting decreases in volume per cell (Fig. 1b). We do not know why the total cell volume decreased near the end of the dark period or how this decrease might be linked to the cell division process. However, when we considered all of the nighttime data, there was no significant time dependent change in total cell volume $(p=0.35$, Table 1), so any apparent decrease at the end of the dark period was roughly balanced by an increase near the beginning (Fig. 1c). The average intracellular DMSP concentration for all diel samples was $259 \pm$ $43 \mathrm{mmol}_{\text {cell }^{-1}}$.

Ratios of intracellular DMSP to other biomass parameters $(\mathrm{C}, \mathrm{N}$, and $\mathrm{chl}$ a) also decreased during the day and increased at night (Fig. 4). Based on linear regressions (Table 2), the DMSP:chl a ratio decreased by $35 \%$ from the beginning to the end of the light period, 
Table 2. Emiliania huxleyi. Results of regressions of the ratio of cellular DMSP:cell volume (mol $1_{\text {cell }}{ }^{-1}$ ) and of molar ratios of cellular DMSP:carbon, cellular DMSP: nitrogen and cellular DMSP:chlorophyll a versus hour of the day for the light and dark growth periods. Slopes $(A$, mean $\pm S E), y$-intercepts $(B$, mean $\pm S E$, number of data $(n)$, p-values, and correlation coefficients $\left(\mathrm{r}^{2}\right)$ are given

\begin{tabular}{|c|c|c|c|c|}
\hline & Cell DMSP:CV & Cell DMSP:C & Cell DMSP:N & Cell DMSP:Chl a \\
\hline \multicolumn{5}{|c|}{ Light } \\
\hline $\mathrm{A}$ & $-0.194 \pm 0.047$ & $-0.007 \pm 0.001$ & $-0.036 \pm 0.01$ & $-46.57 \pm 7.18$ \\
\hline B & $0.310 \pm 0.0127$ & $0.012 \pm 0.0003$ & $0.113 \pm 0.003$ & $67.14 \pm 1.95$ \\
\hline $\mathrm{n}$ & 18 & 18 & 18 & 18 \\
\hline $\mathrm{p}$ & $<0.01$ & $<0.01$ & $<0.01$ & $<0.01$ \\
\hline $\mathrm{r}^{2}$ & 0.52 & 0.67 & 0.42 & 0.72 \\
\hline \multicolumn{5}{|c|}{ Dark } \\
\hline A & $0.185 \pm 0.062$ & $0.006 \pm 0.002$ & $0.033 \pm 0.012$ & $50.35 \pm 10.19$ \\
\hline B & $0.111 \pm 0.049$ & $0.006 \pm 0.001$ & $0.080 \pm 0.010$ & $18.36 \pm 8.00$ \\
\hline $\mathrm{n}$ & 14 & 14 & 14 & 14 \\
\hline $\mathrm{p}$ & 0.01 & $<0.01$ & 0.02 & $<0.01$ \\
\hline $\mathrm{r}^{2}$ & 0.43 & 0.49 & 0.36 & 0.67 \\
\hline
\end{tabular}

while DMSP:cell volume, DMSP:C and DMSP:N showed somewhat smaller decreases of $31 \%, 29 \%$ and $16 \%$, respectively.

\section{Dissolved DMSP and DMS}

The concentrations of dissolved DMSP and DMS were much lower than that of intracellular DMSP. Dissolved DMSP in the cultures varied between 29 and $69 \mathrm{nmol}_{\text {medium }^{-1}}$ (average: $55 \pm 10 \mathrm{nmol}_{\text {medium }^{-1} \text { ) and }}$ DMS ranged from 1.9 to $24 \mathrm{nmol} \mathrm{l}_{\text {medium }}{ }^{-1}$ (average: $10.1 \pm 5.2 \mathrm{nmol}_{\text {medium }^{-1}}$ ). The regressions of the natural log of dissolved DMSP and DMS (corrected for dilution) versus time did not show any significant trend during the day or night $(\mathrm{p}>0.1)$. On a per cell volume basis, dissolved DMSP values ranged from 4.1 to $9.3 \mathrm{mmol}_{\text {cell }}{ }^{-1}$ (average: $6.2 \pm 1.2 \mathrm{mmol}_{\text {cell }}{ }^{-1}$ ), while DMS ranged from 0.3 to $2.5 \mathrm{mmol}_{\text {cell }}{ }^{-1}$ (average: $1.1 \pm$ $0.5 \mathrm{mmol}_{\text {cell }}^{-1}$ ). This is consistent with previous observations that show that nonstressed, nutrient sufficient cells of clone 374 produce little DMS (Sunda et al. 2002). The average dissolved DMSP was only $2.4 \%$ of the average total (particulate plus dissolved) DMSP concentration, confirming that cell lysis was minimal during culture growth and sampling.

\section{DISCUSSION}

\section{Diel variations in intracellular DMSP}

Our study showed significant decreases in intracellular DMSP during the day and increases at night. The exact relative magnitude of the diel changes was dependent on the 'biomass' parameter (cell volume, C, $\mathrm{N}$ or chl a) that DMSP is normalized to.
The observed diel variations have important implications with regard to proposed physiological functions of DMSP. DMSP appears to be a multifunctional molecule. It serves as an osmolyte (Vairavamurthy et al. 1985), has been proposed to function as an active chemical defense mechanism against grazing (Wolfe et al. 1997) and acts as an antioxidant (Sunda et al. 2002, Bucciarelli \& Sunda 2003). In addition, Stefels (2000) hypothesized that DMSP synthesis functions as an overflow mechanism under unbalanced growth. She proposed that at high light intensities or nutrient limitation, when the cell's photosynthetic rate exceeds its capability for protein synthesis, excess fixed carbon may be dissipated into the production of DMSP (Stefels 2000). However, such a photosynthetic overflow mechanism cannot explain the nighttime synthesis of DMSP in our Emiliania huxleyi cultures (Fig. 3a) and also appears to be inconsistent with the lower specific daytime rate of DMSP synthesis relative to that of $\mathrm{C}$ fixation that we observed (Table 1).

The diel variations in intracellular DMSP, however, may be significant with regard to the recently proposed antioxidative function of DMSP (Sunda et al. 2002, Bucciarelli \& Sunda 2003). DMSP and the products of its cleavage and oxidation (DMS, acrylate and DMSO) constitute a cellular antioxidant system involved in the scavenging of hydroxyl radicals, highly toxic reactive oxygen species (Sunda et al. 2002). Oxidative stress occurs from the production of reactive oxygen species (ROS: superoxide radicals, hydrogen peroxide and hydroxyl radicals) via the reaction of reduced components of the photosynthetic or respiratory electron transport chains with molecular oxygen. It also occurs when the excited states of pigments react with molecular oxygen to produce singlet oxygen (Foyer 1996). A diel cycle is commonly observed for antioxidants, like glutathione and superoxide dismu- 
tase (SOD), because ROS generation is linked to photosynthesis and, thus, is highest during the day (Foyer 1996). In cultures of Emiliania huxleyi (clone CCMP 373), cellular concentrations of glutathione were 2 -fold higher during the light period than at night (Dupont et al. 2004). SOD activity was higher during the day in the dinoflagellate Lingulodinium polyedrum (Okamoto \& Colepicolo 2001) and varied diurnally in a fashion similar to DMSP in our study. The circadian rhythm of SOD-activity was linked to daily synthesis of the FeSOD and MnSOD isoforms within chloroplasts and mitochondria, the respective sites of photosynthetic and respiratory ROS production (Okamoto \& Colepicolo 2001). The photosynthetic production of ROS leads to oxidative damage within the chloroplast during the day, as observed in the dinoflagellate L. polyedrum (Cardozo et al. 2002). The compartmentalization of DMSP within algal cells is currently unknown, but in flowering plants DMSP is synthesized within the chloroplast and is primarily localized within that organelle (Trossat et al. 1998).

The increase in intracellular DMSP concentrations and DMSP:Chl a ratios during the night and resulting highest levels at the beginning of the light period (Figs. 3c \& 4a) is consistent with an antioxidant function for DMSP. A high DMSP:chl a ratio in the early morning, as we observed, may be particularly important in the natural environment since light increases continuously during that time with resultant increases in chl a light absorption, photosynthesis and attendant ROS production. Thanks to biological clocks, organisms have the capacity to cope with predictable higher levels of oxidative stress, such as that associated with day:night cycles (Okamoto \& Colepicolo 2001). Our cells of Emiliania huxleyi, which were acclimated to the same daily light:dark cycle over several generations appear to be able to adjust their intracellular DMSP concentrations and DMSP:chl a ratios to highest values just before the return of the light in early morning and the associated increase in oxidative stress from photosynthesis.

\section{Comparisons with in situ studies}

Very few studies have focused on the diel cycles of DMSP and almost all of these have been in situ studies, which are often difficult to interpret with regard to causative mechanisms. In surface waters where Emiliania huxleyi blooms, DMSP represents on average $8 \%$ of algal carbon $(5.3 \pm 0.6 \%$ in our study) and its rate of production has been reported to be closely correlated to primary production rates (Simo et al. 2002). In a deck incubation experiment, computed DMSP production rates exhibited a diurnal pattern similar to those of photosynthetic carbon fixation (Simo et al. 2002), apparently confirming earlier assumptions that DMSP biosynthesis is a light dependent process that does not occur at night (Simo \& Pedros-Alio 1999, Simo et al. 2000). However, the DMSP production rates determined in the above experiment were based on net changes in particulate DMSP concentration and calculated DMSP loss rates in the dark that assumed no dark production of DMSP. Thus, the conclusions are questionable since the 'observed' lack of DMSP production at night was based on the assumption of zero dark production.

Our results clearly showed a continuous production of DMSP during the diel cycle, with approximately a $30 \%$ lower specific rate of biosynthesis during the night (Table 1). Nighttime synthesis of DMSP has also been observed in axenic cultures of another high DMSP prymnesiophyte, Phaeocystis sp. (Stefels et al. 1996). We regressed the natural log of cellular DMSP (in nmol $l_{\text {medium }}{ }^{-1}$ ) versus time based on the data presented by Stefels et al. (1996) in their Fig. 5. The regression yielded a specific rate of DMSP synthesis of ca. $1.3 \mathrm{~d}^{-1}$ during the day and ca. $0.5 \mathrm{~d}^{-1}$ at night. These values are similar to those we observed for Emiliania huxleyi, which also show a lower rate of production during the night. Thus, both studies indicate nighttime production of DMSP for these two major DMSP producers. Such nighttime production will have to be taken into account in assessing the different processes that affect DMSP and DMS concentrations in ocean waters. For example, previous modeled estimates of DMSP loss and production rates in ocean waters based on an assumed lack of dark DMSP biosynthesis may need to be reassessed.

Our results clearly showed diel variations in cellular DMSP:chl a ratios. We observed a decrease in the DMSP:chl a molar ratio during the day from an average of 67 at the beginning of the light period to 44 at the end. By contrast, DMSP:chl a ratios are generally observed to increase during the day in natural seawater. In surface waters of the Ligurian Sea, Belviso et al. (2000) noted low DMSP:chl a values at dawn (49) and high values at dusk (up to 250). Likewise in the St. Lawrence Estuary, Merzouk et al. (2004) measured surface DMSP:chl a molar ratios between 0.9 and 14 , with the lowest values at night and a peak at noon. These diel patterns were largely explained by diel variations in the abundance of vertically migrating dinoflagellates, which contain high intracellular DMSP concentrations (Belviso et al. 2000, Merzouk et al. 2004). In an oligotrophic site in a barrier reef system, Sunda et al. (2005) also found an increase in DMSP: chl a molar ratio during the day and a decrease at night (values between 10.5 and 55.6), but the basis for this pattern was not readily apparent. 
In this culture study, the diel pattern in DMSP:chl a can be attributed to diel differences in net specific rates of DMSP and chl a synthesis, with a higher specific rate of chl a synthesis during the day relative to that of DMSP, and a higher net rate of DMSP synthesis at night (Table 1). However, as noted above, diel variations in the field may largely reflect diel variations in the species composition of the algal community resulting from vertical migration of motile algal species (e.g. dinoflagellates) or grazing zooplankton. Consequently, it is difficult to infer physiologically linked variations in DMSP to biomass ratios within algal cells solely from field observations. Clearly, there is a need for culture studies, such as that presented here, to establish such linkages.

\section{CONCLUSIONS}

We observed significant cellular production of DMSP during the night for a major DMSP producer, the coccolithophorid Emiliania huxleyi. Nighttime synthesis of DMSP has also been observed in axenic cultures of another high DMSP prymnesiophyte, Phaeocystis sp. (Stefels et al. 1996). Further experiments, however, may be needed to assess whether nighttime production is commonplace in DMSP producing phytoplankton. If it is, then nighttime biosynthesis of DMSP will need to be included in models of DMSP and DMS dynamics in ocean waters.

We also observed diel differences in intracellular DMSP per unit of cell volume, $\mathrm{C}, \mathrm{N}$ and chl $a$, with highest values found at the beginning of the light period. Such a diel pattern is consistent with the proposed antioxidant function for DMSP, but future work will be needed to assess whether this pattern occurs in other DMSP producing phytoplankton, and whether other parts of the DMSP-DMS system, such as the activity of DMSP lyase enzymes or cellular production of the DMSP oxidation product DMSO also exhibit diel patterns. Our results suggest that time of day needs to be considered in sampling DMSP in ocean waters and in interpreting the results of incubation experiments with natural planktonic assemblages.

Acknowledgements. The authors thank 2 anonymous reviewers for their useful comments and A. Masson for carbon and nitrogen determination. This is Contribution No. 1030 of the IUEM, European Institute for Marine Studies (Brest, France).

\section{LITERATURE CITED}

Belviso S, Christaki U, Vidussi F, Marty JC, Vila M, Delgado M (2000) Diel variations of the DMSP-to-chlorophyll a ratio in Northwestern Mediterranean surface waters. J Mar Syst 25:119-128
Bucciarelli E, Sunda WG (2003) Influence of $\mathrm{CO}_{2}$, nitrate, phosphate and silicate limitation on intracellular DMSP in batch cultures of the coastal diatom Thalassiosira pseudonana. Limnol Oceanogr 48:2256-2265

Cardozo KHM, de Oliveira MAL, Tavares MFM, Colepicolo P, Pinto E (2002) Daily oscillation of fatty acids and malondialdehyde in the dinoflagellate Lingulodinium polyedrum. Biol Rhythm Res 33:371-382

Charlson RJ, Lovelock JE, Andreae MO, Warren SG (1987) Oceanic phytoplankton, atmospheric sulfur, cloud albedo and climate. Nature 326:655-661

Cuhel RL, Ortner PB, Lean DRS (1984) Night synthesis of protein by algae. Limnol Oceanogr 29:731-744

Dupont CL, Goepfert TJ, Lo P, Wei L, Ahner BA (2004) Diurnal cycling of glutathione in marine phytoplankton: field and culture studies. Limnol Oceanogr 49:991-996

Falkowski PG, Kim Y, Kolber Z, Wilson C, Wirick C, Cess R (1992) Natural versus anthropogenic factors affecting lowlevel cloud albedo over the North Atlantic. Science 256: 1311-1313

Foyer CH (1996) Free radical processes in plants. Biochem Soc Trans 24:427-433

IPCC (2001) Climate change 2001: the scientific basis. Available at: http://www.grida.no/climate/ipcc_tar/wg1/ index.htm

Keller MD, Bellows WK, Guillard RRL (1989) Dimethylsulfide production in marine phytoplankton. In: Saltzman ES, Cooper WJ (eds) Biogenic sulfur in the environment. American Chemical Society, Washington, DC, p 167-182

Kiene RP (1990) Dimethylsulfide production from dimethylsulfoniopropionate in coastal seawater samples and bacterial cultures. Appl Environ Microbiol 56:3292-3297

Lorensen CJ (1966) A method for the continuous measurement of in vivo chlorophyll concentration. Deep-Sea Res 13:223-227

Merzouk A, Levasseur M, Scarratt M, Michaud S, Gosselin M (2004) Influence of dinoflagellate diurnal vertical migrations on dimethylsulfoniopropionate and dimethylsulfide distribution and dynamics (St. Lawrence Estuary, Canada). Can J Fish Aquat Sci 61:712-720

Okamoto OK, Colepicolo P (2001) Circadian protection against reactive oxygen species involves changes in daily levels of the manganese- and iron-containing superoxide dismutase isoforms in Lingulodinium polyedrum. Biol Rhythm Res 32:439-448

Paasche E (1967) Marine plankton algae grown with light dark cycles. I. Coccolithus huxleyi. Physiol Plant 20: 946-956

Paasche E (1998) Role of nitrogen and phosphorus in coccolith formation in Emiliania huxleyi (Prymnesiophyceae). Eur J Phycol 33:33-42

Simó R, Pedrós-Alió C (1999) Short-term variability in the open ocean cycle of dimethylsulfide. Global Biogeochem Cycles 13:1173-1181

Simó R, Pedrós-Alió C, Malin G, Grimalt JO (2000) Biological turnover of DMS, DMSP and DMSO in contrasting opensea waters. Mar Ecol Prog Ser 203:1-11

Simó R, Archer S, Pedrós-Alió C, Gilpin L, Stelfox-Widdicombe CE (2002) Coupled dynamics of dimethylsulfoniopropionate and dimethylsulfide cycling and the microbial food web in surface waters of the North Atlantic. Limnol Oceanogr 47:53-61

Stefels J (2000) Physiological aspects of the production and conversion of DMSP in marine algae and higher plants. J Sea Res 43:183-197

Stefels J, van Boekel WHM (1993) Production of DMS from dissolved DMSP in axenic cultures of the marine 
phytoplankton species Phaeocystis sp. Mar Ecol Prog Ser 97:11-18

Stefels J, Gieskes WWC, Dijkhuizen L (1996) Intriguing functionality of the production and conversion of DMSP in Phaeocystis sp. In: Kiene RP, Visscher PT, Keller MD, Kirst GO (eds) Biological and environmental chemistry of DMSP and related sulfonium compounds. Plenum Press, New York, p 305-315

Sunda W, Kieber DJ, Kiene RP, Huntsman S (2002) An antioxidant function for DMSP and DMS in marine algae. Nature 418:317-320

Sunda WG, Litaker RW, Hardison DR, Tester PA (2005) Dimethylsulfoniopropionate (DMSP) and its relation to algal pigments in diverse waters of the Belize coastal lagoon and barrier reef system. Mar Ecol Prog Ser 287: $11-22$

Sunda WG, Hardison R, Kiene R, Bucciarelli E, Harada H (2007) The effect of nitrogen limitation on cellular DMSP

Editorial responsibility: Hugh MacIntyre,

Dauphin Island, Alabama, USA and DMS release in marine phytoplankton: climate feedback implications. Aquat Sci (in press)

Trossat C, Rathinasabapathi B, Weretilnyk EA, Shen TL, Huang ZH, Gage DA, Hanson AD (1998) Salinity promotes accumulation of 3-dimethylsulfoniopropionate and its precursor S-methylmethionine in chloroplasts. Plant Physiol 116:165-171

Vairavamurthy A, Andreae MO, Iverson RL (1985) Biosynthesis of dimethylsulfide and dimethylpropiothetin by Hymenomonas carterae in relation to sulfur source and salinity variations. Limnol Oceanogr 30:59-70

Westbroek P, Brown CW, van Bleijswijk J, Brownlee C and 10 others (1993) A model system approach to biological climate forcing. The example of Emiliania huxleyi. Global Planet Change 8:27-46

Wolfe GV, Steinke M, Kirst GO (1997) Grazing-activated chemical defence in a unicellular marine alga. Nature 387 : 894-897

Submitted: September 18, 2006; Accepted: March 25, 2007 Proofs received from author(s): May 22, 2007 